\title{
Czy można funkcjonować poza schematem? Recenzja książki Poza schematem. Społeczny konstrukt płci i seksualności
}

Tytuł: Poza schematem. Społeczny konstrukt płci i seksualności

Autorzy: Urszula Kluczyńska Wiktor Dynarski, Anna M. Kłonkowska,

Wydawnictwo: Wydawnictwo Uniwersytetu Gdańskiego

Rok wydania: 2016

Liczba stron: 146

Michał Bomastyk

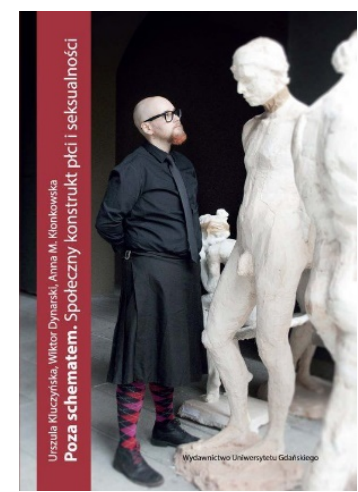

Instytut Filozofii

Uniwersytet Mikołaja Kopernika

michalbomastyk@gmail.com

Przyjęto: 27 marca 2017; zaakceptowano: 5 czerwca 2017.

\begin{abstract}
Abstrakt
W tekście dokonuję przeglądu książki Poza schematem. Społeczny konstrukt ptci i seksualności autorstwa Urszuli Kluczyńskiej, Wiktora Dynarskiego oraz Anny Kłonkowskiej. Jest to bardzo interesująca lektura, ponieważ opisuje uwikłanie w binarny system płciowy „męskie-kobiece” tak zwanych osób niebinarnych, zwłaszcza transpłciowych. Autorzy zastanawiają się, jakie kroki należałoby podjąć, żeby osoby niebinarne czuły się swobodnie w społeczeństwie i w sposób wolny, z dala od opresyjnej heteronormy, mogły konstruować swą podmiotowość. Autorzy przekonują, że jest to możliwe wyłącznie poza (binarnym) schematem, który należy zdestabilizować. W recenzji zastanawiam się, czy wyjście z jednego schematu nie jest, paradoksalnie, wejściem w kolejny.
\end{abstract}

Słowa kluczowe: schemat; heteronorma; transpłciowość; cispłciowość; binarny system płciowy 
W Słowniku Języka Polskiego PWN czytamy, że schematem jest „gotowy wzór czegoś, powielany potem wielokrotnie” (Stownik Języka Polskiego PWN, 2017). Możemy wyróżnić wiele schematów stabilizujących i podtrzymujących rzeczywistość społeczną, w której żyjemy, na przykład schematy językowe (konstrukcje zdaniowe), biologiczne (RNA, DNA), matematyczne (kolejność wykonywania działań czy wzory skróconego mnożenia) etc. Schematy mogą również być myślowe, a także dotyczyć sposobu postrzegania rzeczywistości i na nie chciałbym zwrócić szczególnie moją uwagę. Dostosowanie się do któregokolwiek z nich oznacza bowiem postępowanie zgodnie z jego założeniami, czego konsekwencją jest przyjęcie ściśle określonego (świato)poglądu. Co więcej, jeśli chcemy nauczyć się konkretnego schematu, to musi on być przez nas wielokrotnie powtarzany. W ten sposób poprawnie go zapamiętujemy, dzięki czemu unikamy błędów przy ponownym jego odtwarzaniu.

Schematów myślenia i postępowania uczymy się od najmłodszych lat w procesie socjalizacji. Wówczas dowiadujemy się o normach zachowania mówiących o tym, jakie działania powinniśmy podejmować, aby poprawnie funkcjonować w społeczeństwie, przykładowo, jakie wartości przyjąć, w jaki sposób myśleć, jakie ubrania nosić oraz jakich słów używać. Moglibyśmy pokusić się o postawienie tezy, że każdy z nas tego rodzaju schematów uczy się po to, by móc posiąść umiejętność, jaką jest kategoryzowanie świata. Każdy z nas bowiem analizuje kulturową rzeczywistość: wyszukujemy podobieństwa oraz różnice i na tej podstawie kategoryzujemy - porządkujemy swą „,̇yciową przestrzeń”. Możemy także proces ten dookreślić jako matrycowanie kultury, podczas którego schematyzujemy każdy fragment społecznej rzeczywistości po to, aby w przyszłości mógł być podobnie odczytany zarówno przez nas, jak i przez inne osoby. Oznacza to, że wytwarzamy spójne matryce ${ }^{1}$ spojrzeń (Bourdieu, 2004), które każda jednostka z danego kręgu kulturowego jest w stanie zrozumieć i się nimi posłużyć, by móc także kategoryzować rzeczywistość. Zauważmy również, że matrycujemy, kategoryzujemy otaczający nas świat, ponieważ w ten sposób go racjonalizujemy (podporządkowujemy sobie i upraszczamy), czynimy to zaś dlatego, że wtedy jest nam łatwiej w nim uczestniczyć ${ }^{2}$. Co więcej, konstruujemy wówczas stereotypy, czyli „funkcjonując[e] w świadomości społecznej uproszczon[e] i zabarwion[e] wartościująco obrazy rzeczywistości” (Słownik Języka Polskiego PWN, 2017).

\footnotetext{
${ }^{1}$ Matryca jest spójnym układem, który wykorzystujemy w celu postrzegania rzeczywistości społeczno-kulturowej i jej projektowania. Pierre Bourdieu mianem matrycy dookreśla habitus, to jest nabyte przez nas umiejętności, które z czasem przyjmują postać trwałych dyspozycji. Judith Butler z kolei zaznacza, że matryca odpowiada za tworzenie „[...] regulatywnych praktyk produkujących spójne tożsamości” (Butler, 2008, s. 69)
}

${ }^{2}$ Pisał o tym Walter Lippmann w książce Public Opinion (1922). 
Należy także podkreślić, że schematy, które poznajemy oraz wytwarzamy w procesie socjalizacji są „typowo męskie” bądź „typowo kobiece”. Kultura, w której żyjemy, jest konstruowana w oparciu o binarne opozycje: dobry-zły, prawy-lewy, mężczyzna-kobieta etc., których człony są różnie wartościowane. Możemy zatem sformułować wniosek, że socjalizujące schematy opisują także sposób, w jaki jednostki powinny przeżywać swą płciowość, to znaczy poprawnie funkcjonować w przestrzeni społecznej jako mężczyźni bądź kobiety. Mężczyźni są zatem zobowiązani do posługiwania się „męskimi” schematami oraz do „męskiego” matrycowania rzeczywistości, kobiety natomiast muszą kategoryzować świat przy użyciu „kobiecych” schematów. Judith Butler w książce Uwikłani $w$ płeć pisze, że w procesie płciowej socjalizacji uczymy się „prawdy płci”, czyli „matrycy [podkr. M.B.] spójnych norm płciowych” (2008, s. 69). W tym miejscu dookreślmy, że główną determinantą „bycia kobietą” bądź „bycia mężczyzną” (a zatem binarnej „prawdy płci”) w społeczeństwach zachodnioeuropejskich jest posiadanie „kobiecych” bądź „męskich” genitaliów. Takie kategoryzowanie świata wpisuje się w esencjalistyczny paradygmat, w myśl którego esencja wyprzedza egzystencję ${ }^{3}$. Kulturowy wizerunek płci powinien zatem - zgodnie z założeniami binarnego schematu, systemu płciowego - wynikać z uposażenia anatomicznego jednostki. Co więcej, kobiety i mężczyzn obowiązuje również norma heteroseksualna, co oznacza, że jednostki muszą swą seksualność potwierdzać wyłącznie w heteroseksualnej relacji intymnej (Butler, 2008, s. 77).

Takie status quo jest niezwykle krzywdzące dla jednostek niebinarnych, które nie wpisują się w obowiązujący społeczno-kulturowy schemat. Dotyczy to przede wszystkim osób homoseksualnych, biseksualnych, transseksualnych ${ }^{4}$, interseksualnych, aseksualnych, a także osób o tożsamości typu queer ${ }^{5}$, które $\mathrm{z}$ racji nienormatywnej tożsamości płciowej nie mogą realizować w swych jednostkowych egzystencjach heteroseksualnej normy. Jeśli nawet próbują to czynić (por. Lis, 2015), wówczas wydaje się, że ich egzystencje są

\footnotetext{
${ }^{3}$ Esencja w filozofii stanowi naturę, istotę bytu. Esencjalizm zaś zakłada, że byt posiada swą ukrytą istotę, która konstytuuje jego istnienie. W filozofii egzystencjalnej, zwłaszcza w rozważaniach JeanPaula Sartre’a, pogląd ten spotkał się z dużą krytyką. W egzystencjalizmie zakłada się, że życie człowieka jest jego własnym, wolnym projektem (Sartre, 1998, s. 52), że to on sam siebie stwarza, a także, że nie ma nad sobą innego prawodawcy, gdyż jest nim on sam (Sartre, 2007, s. 82). Co więcej, realizując swój egzystencjalny projekt, nie jest niczym zdeterminowany. Filozofia egzystencjalna jest zatem antyesencjalistyczna - nie zakłada gotowej, pierwotnej natury, istoty bytu, w myśl zasady, że to egzystencja poprzedza esencję.

${ }^{4}$ Transseksualność to „zjawisko odnoszące się do sytuacji osoby, której płeć odczuwana nie odpowiada płci fizycznej, lecz płci powszechnie uważanej za przeciwną” (Kłonkowska, Dynarski, 2016, s. 19). Interseksualność natomiast to „cechowanie się właściwościami różnorodnymi płciowo w obrębie rozwoju jednego lub wielu aspektów płci” (2016, s. 16). Dodajmy także, że transpłciowość to „zbiorcza nazwa dla osób wykraczających poza tradycyjny, jednoznaczny podział na płeć męską i żeńską" (2016, s. 19).

${ }^{5}$ Zapewne moglibyśmy podać jeszcze wiele strategii tożsamościowych (Kłonkowska, Dynarski, 2016, ss. 13-20), aczkolwiek te, jak się zdaje, są najczęściej spotykane. Na nie składa się skrót LGBTQIA.
} 
nieautentyczne, gdyż nie mogą konstruować własnej podmiotowości w sposób wolny ${ }^{6}$. Poddają się więc opresyjnej heteronormie i próbują dopasować do binarnego schematu, ponieważ w ten sposób mogą uniknąć ostracyzmu społecznego. Osoby niebinarne powinny mieć możliwość wyjścia poza opisywany schemat, co zaproponowali i do czego przekonują Urszula Kluczyńska, Wiktor Dynarski oraz Anna Kłonkowska w książce Poza schematem. Społeczny konstrukt ptci i seksualności.

Książka jest zbiorem tekstów Autorek i Autora. Kluczyńska w swych dwóch artykułach zwraca uwagę na problem medykalizacji męskiej seksualności oraz socjalizacji do męskości, Kłonkowska pisze o społecznym konstruowaniu seksualności w odniesieniu do osób transpłciowych, Dynarski w swych artykułach natomiast zwraca uwagę na problem wykluczenia, którego doświadczają osoby transpłciowe, a także zastanawia się nad rozwiązaniami społeczno-prawnymi, dzięki którym osoby niebinarne mogłyby w zgodzie z własnym „ja” realizować egzystencjalny projekt. Twierdzi on, między innymi, że wprowadzenie obok kategorii płciowych „mężczyzna” i „kobieta” kategorii „inna” nie jest wystarczające, a wręcz jest przejawem cisnormatywnej opresji (2016c, s. 24). Konstruowanie trzeciej opcji jest dla badacza „tworzenie[m] przestrzeni ostracyzmu” (2016c, s. 25), ponieważ w sposób niezwykle wyraźny naznacza ona osoby transpłciowe ową „innością”», co może być przyczyną ich społecznego wykluczenia. Zdaniem Dynarskiego należy tak poszerzyć trzecią płciową opcję, żeby nie miała ona charakteru wyobcowującego, stygmatyzującego. Autor podaje przykład badania społecznego osób transpłciowych, w którym do sformułowania „Jestem...” można było ustosunkować się w następujący sposób: „osobą transpłciową, osobą transseksualną, osobą transgenderową, osobą transwestytyczną, crossdresserem/crossdresserką, osobą interpłciową (interseksualną, hermafrodytyczną), osobą queer, osobą $\mathrm{m} / \mathrm{k}$, osobą $\mathrm{k} / \mathrm{m}$, kobietą $\mathrm{z}$ transseksualną lub transpłciową przeszłością, mężczyzną z transseksualną lub transpłciową przeszłością, po prostu kobietą, po prostu mężczyzną, nie wiem, nie chcę stwierdzić, inne” (2016c, ss. 30-31). Zaproponowane odpowiedzi niewątpliwie pozwalają dookreślić się jednostkom niebinarnym w różnorodny

\footnotetext{
${ }^{6}$ Pisząc, że egzystencje osób niebinarnych są nieautentyczne nie mam na myśli tego, że są one w jakiś sposób niepoukładane, wypaczone czy gorsze od egzystencji jednostek cispłciowych. Nie twierdzę także, że osoby niebinarne same w sobie są nieautentyczne. W zdaniu tym wyrażam jedynie tezę, że osoby niebinarne nie mogą swobodnie realizować swej nienormatywnej strategii tożsamościowej, gdyż podlegają opresyjnej cisnormie, dyskredytującej ich autentyczność. Nie mogą one bez skrępowania dookreślać wła s nej tożsamości, ponieważ ciąży na nich obowiązek dopasowania się do jednej ze stron binarnego systemu płciowego. Konsekwencją tego jest nieautentyczna - niepozostająca w zgodzie z „ja” niebinarnej jednostki - egzystencja.

${ }^{7}$ W recenzowanej przeze mnie książce czytamy: „Cisnormatywność - konfiguracja kulturowa sprowadzająca płciowość do konieczności jednoznacznej identyfikacji z płcią oznaczoną po urodzeniu. Kultura cisnormatywna [...] wyklucza tożsamości i doświadczenia transpłciowe, definiując je w kategoriach marginesu, anomalii, degeneracji lub dewiacji” (Kłonkowska, Dynarski, 2016, s. 13).

${ }^{8} \mathrm{~W}$ dalszej części pracy odniosę się do inności z perspektywy filozofii egzystencjalnej i nie będzie ona oznaczała, jak w tym przypadku, dziwności i odmienności.
} 
sposób. Co więcej, mają charakter inkluzywny, to znaczy równościowy - nikogo nie deprecjonują ani nie marginalizują. Taka wielość odpowiedzi dostarcza bowiem, jak podkreśla to Dynarski, „możliwość pozycjonowania się w kilku miejscach dyskursu” (2016c, s. 31). Jest to bardzo ważne dla osób niebinarnych, szczególnie zaś dla jednostek transpłciowych, które nierzadko doświadczają dyskryminacji oraz opresji ze względu na swoją nienormatywną tożsamość.

Wykluczenie osób transpłciowych wynika z tego, że „wszystko obraca się wokół konstytuowania relacji na podstawie zakorzenionych w społeczeństwie ogólnych twierdzeń na temat możliwości biologicznych ciał widzianych jedynie z perspektywy cisnormatywnej” (Dynarski, 2016a, s. 72), dlatego Autorzy proponują wyjście poza dyskurs genitalny (Dynarski, 2016a, s. 74). Jest to odważny, ale bardzo potrzebny postulat, gdyż dopiero wówczas będziemy w stanie zrozumieć problemy i trudności towarzyszące osobom transpłciowym, które nierzadko nie klasyfikują się jako jednostki cispłciowe ${ }^{9}$. Dynarski postuluje zatem, aby polityka płciowa zmierzała $\mathrm{w}$ stronę transpłciowej reprezentacji (2016d, s. 133-145) tak, by każda jednostka w społeczeństwie mogła w sposób wolny, sprawczy i zarazem odpowiedzialny konstruować własną podmiotowość. Pozostaje jednak pytanie, w jak należałoby doprowadzić do ustabilizowania się w przestrzeni społeczno-kulturowej transpłciowej reprezentacji? Pierwszym krokiem prowadzącym do proponowanego przez Dynarskiego celu byłaby niewątpliwie zmiana systemu prawnego na taki, w którym prawo nie dyskryminuje osób niebinarnych. Kolejna modyfikacja powinna objąć przestrzeń językową i polegać na ponownym skonstruowaniu języka oraz nadaniu mu cech inkluzywnych ${ }^{10}$.

Postulat transpłciowej reprezentacji niewątpliwie powinien zostać wcielony w życie. Wydaje się jednak, że jest to bardzo skomplikowane przedsięwzięcie zakładające przebudowę społeczeństwa (Dynarski, 2016d, s. 141) na wzór transgenderowy, w którym każda jednostka (także cispłciowa) będzie mogła swobodnie dookreślać swą płciową tożsamość. Proponowana przez Dynarskiego przebudowa społeczeństwa wiązałaby się $\mathrm{z}$ destabilizacją funkcjonujących schematów myślenia i postępowania, heteronormy, heteroseksualnej „prawdy płci”, a także dotychczasowych kategorii, którymi posługujemy się podczas matrycowania świata. $\mathrm{W}$ tym miejscu nasuwa się pytanie, czy świat, który dotychczas wydawał się dla nas racjonalny, ponieważ był przez nas uproszczony, nie stałby się wówczas miejscem, którego nie rozumiemy, którego się boimy? Typ transgenderowego społeczeństwa byłby bowiem pozbawiony owych uproszczeń. Zdaję sobie sprawę z tego, że propozycję budowy transgenderowego społeczeństwa omawiam z perspektywy cisnormatywnej, jednak w

\footnotetext{
${ }^{9}$ Autorzy Poza schematem wyjaśniają: „Cispłciowość - termin stosowany [...] na określenie osób utożsamiających się z rozpoznaną w momencie narodzin płcią (Kłonkowska, Dynarski, 2016, s. 14).

${ }^{10}$ Dynarski zwraca uwagę, że w Stanach Zjednoczonych proponuje się, aby osoby transpłciowe mogły mówić o sobie używając zaimka osobowego liczby mnogiej they (2016c, ss. 23-24).
} 
mojej ocenie należy wziąć pod uwagę także zdanie podobnych do mnie osób, ponieważ żyjemy $\mathrm{w}$ rzeczywistości społecznej stabilizowanej i podtrzymywanej przez heteronormę. Wydaje się więc, że najpierw należałoby zwrócić się ku osobom cispłciowym i ukazać im inne możliwości konstruowania własnej podmiotowości oraz tożsamości płciowej, odmienne od aktualnie obowiązującego społeczno-kulturowego, heteroseksualnego wizerunku męskości i kobiecości. Dynarski pisze: „To, co wydaje się interesujące i nadal pozostaje w przestrzeni projektu, to pytanie, jak wyglądałyby wyniki badań tożsamości i doświadczeń przeprowadzone na osobach cispłciowych - być może otworzyłoby dyskusję na temat tego, w jaki sposób przedstawiają się zarówno identyfikacje, jak i doświadczenia normotwórczej grupy” (2016c, s. 36). Rzeczywista zmiana postaw osób cispłciowych względem osób niebinarnych i zwrócenie uwagi na to, że mogą one dookreślać swą płciową tożsamość w inny sposób aniżeli wyłącznie męski bądź kobiecy oraz heteroseksualny, rzeczywiście może doprowadzić do destabilizacji społecznego status quo, w którym osoby niebinarne są pomijane i marginalizowane, w którym „[...] klasyfikacje, definicje i przeciwstawienia prowadzą w konsekwencji do hierarchizowania i ekskluzji” (Kłonkowska, 2016, s. 113).

Dynarski, pisząc o transpłciowej reprezentacji, zauważa, że neoliberalizm odegrał dużą rolę w kształtowaniu się postaw społeczeństwa obywatelskiego, jak również w szerzej pojętym procesie demokratyzacji, „podczas którego powstają kolejne inicjatywy obywatelskie, organizacje pozarządowe, kolektywy oraz inne formy aktywizacji politycznej” (Dynarski, 2016d, s. 135). W tym fragmencie dostrzegam cichą pochwałę Dynarskiego systemu neoliberalnego, który niewątpliwie uposaża jednostki w wiele swobód obywatelskich i gospodarczych, a także w dużą dozę wolności. Należy jednakże dookreślić, że myślenie neoliberalne jest ściśle skorelowane z systemem kapitalistycznym nastawionym na indywidualny (wy)zysk jednostki, zwłaszcza finansowy. Co więcej, myślenie neoliberalne nie jest inkluzywne, bynajmniej - dyskryminuje jednostki niżej sytuowane społecznie. Andrzej Szahaj pisze o neoliberalnym kapitalizmie, że jest brutalny oraz wytwarza nową kastę ludzi: „Nade wszystko bezwzględność, egoizm i chamstwo. Poczucie, że wygranych nikt nie ma prawa sądzić w świetle jakichś standardów etycznych wykraczających poza prostą (prostacką?) pochwałę zdecydowania, uporu, siły charakteru i indywidualnej mocy działania. Wszystko to owocuje powstaniem nowej kasty ludzi, którzy z rzeczy tradycyjnie uznawanych za zło (arogancja, pycha, bezwzględność) czynią cnotę. [...] Do tego dochodzi kompletny brak empatii, umiejętności wczucia się w nastroje i emocje innego" (2015c, ss. 24-25).

Motto systemu kapitalistyczno-neoliberalnego zdaniem Szahaja brzmi: „Poniżam, więc jestem”. Co więcej, nie przynależy do niego ani „pojęcie dobra wspólnego, ani pojęcie wspólnoty, na rzecz której warto czasami ponieść ofiary” (Szahaj, 2015, s. 25). Uważam zatem, że posługiwanie się kategorią ne- 
oliberalizmu nie jest dobrym działaniem na rzecz tego, by wyrównywać nierówności w społeczeństwie demokratycznym oraz zwracać uwagę na potrzeby osób niebinarnych, zwłaszcza transpłciowych System neoliberalno-kapitalistyczny jednych obywateli czyni bardziej wartościowymi, innych natomiast całkowicie pomija, szczególnie tych, którzy nie wpisują się w pożądaną normę społeczną. Widzimy zatem, że system ten w żaden sposób nie dba o równe szanse dla wszystkich ${ }^{11}$. Uważam, że należy to podkreślić $\mathrm{w}$ kontekście omawianej przeze mnie książki.

Dynarski odwołuje się także do figury Innego, inspirowany - jak sam to ujął rozważaniami Jacques’a Lacana (2016d, ss. 134-135). Ja natomiast chciałbym poszerzyć rozważania Dynarskiego na temat „innego”, odwołując się do filozofii egzystencjalnej. Inny w filozofii Jean-Paula Sartre’a zajmuje ważne miejsce w mojej egzystencji, ponieważ kształtuje moje doświadczenia, wpływa na moje postępowanie, może mnie zawstydzać i jest łącznikiem „między moim «ja» a mną samym” (Sartre, 2007, ss. 293, 288). Bez relacji z innym nie mógłbym realizować swojego egzystencjalnego projektu i konstruować własnej podmiotowości, ponieważ wybierając za siebie wybieramy zawsze za innych (1998, s. 29-30). Oznacza to, że jeśli chcę rzeczywiście egzystować jako wolny, sprawczy podmiot, to muszę być odpowiedzialny nie tylko za siebie samego, lecz za cały świat (w tym za innego) (por. Sartre, 2007, s. 680). Na temat odpowiedzialności pisał również francuski filozof Emmanuel Lévinas. Stwierdził on, że człowiek może wziąć odpowiedzialność za drugiego dopiero wtedy, gdy spotka się z nim twarzą w twarz, gdy Inny da się jemu poznać - gdy odkryje przed nim swoje tajemnice. Spotkanie twarzą w twarz jego zdaniem jest „odpowiedzialnością, nawiedzeniem przez innego, byciem jeden-za-drugiego, narodzinami znaczenia ponad byciem” (Lévinas, 2000, s. 152). Dostrzegając twarz Innego mogę zrozumieć, jak bardzo Inny potrzebny jest mojej egzystencji. Co więcej, spotkanie twarzą w twarz z Innym pozwoli mi wziąć za niego odpowiedzialność i transcendować - przekraczać granice własnego człowieczeństwa (por. De Beauvoir, 2014, s. 93). Przyjmijmy, że Innym jest osoba transpłciowa, która $\mathrm{w}$ cisnormatywnym społeczeństwie zostaje pozbawiona twarzy - jest bardziej Obca aniżeli Inna, ponieważ wykluczona poza społeczeństwo, dookreślana nierzadko jako „wynaturzona”. A przecież osoby transpłciowe mogą wiele wnieść do społeczeństwa, zwracać uwagę na to, że świat nie jest czarno-biały, lecz barwny i różnorodny, że jest w nim miejsce dla wielu strategii tożsamościowych. Należy zatem tak organizować politykę społeczną i płciową, aby umożliwiać jednostkom żyjącym w społeczeństwie

\footnotetext{
${ }^{11}$ Warto także wspomnieć w tym miejscu o książce Jedyna płeć szwedzkiej feministki Katrine Kielos (2014), w której Autorka opisuje, jak system neoliberalno-kapitalistyczny wyklucza kobiety z globalnej, ekonomicznej przestrzeni.
} 
poznawać twarz Innego: tego, co nie-cispłciowe, co nienormatywne, co niebinarne. W ten sposób osoby zanurzone w heteronormie będą mogły dostrzec płciową różnorodność w świecie i co najważniejsze poznać twarz Innego, zrozumieć go, szanować i zaakceptować - wziąć za niego odpowiedzialność.

Książka Poza schematem zwraca uwagę na to, że osoby transpłciowe próbuje uczynić się w społeczeństwie zachodnioeuropejskim niezauważalnymi. Chce je się na siłę dopasować - zgodnie $\mathrm{z}$ obowiązującą heteronormą - do jednej z dwóch opozycji binarnego systemu płciowego: męskiej bądź kobiecej. Wniosek płynący z tej książki jest taki, że należy dać wszystkim jednostkom żyjącym w społeczeństwie swobodę dookreślania własnej podmiotowości, w tym przede wszystkim płciowości, tak aby nie musiała być ona skorelowana wyłącznie z wypełnianiem „męskiego” bądź „kobiecego” schematu postępowania, lecz żeby wyrażała ogólną postawę wobec istnienia, tak jak opisała to Simone de Beauvoir: „[...] życiem jednostki nie rządzi żadne seksualne przeznaczenie; na odwrót, erotyzm jednostki wyraża jej ogólną postawę wobec istnienia” (2014, s. 473).

Pozostaje jednak pytanie, na które Autorzy książki zdają się nie odpowiadać, a mianowicie, czy wyjście poza cisnormatywny schemat nie będzie, paradoksalnie, wejściem w kolejny? Wydaje się bowiem, że zmiana jednego paradygmatu płciowego doprowadzi do ukonstytuowania się kolejnego, poprzez który wytworzą się kolejne normy, w tym „prawda płci”, a także nowe schematy i kategorie służące do matrycowania rzeczywistości. Wydaje się zatem, że propozycja skonstruowania społeczeństwa, w którym jednostki będą mogły żyć poza schematem, jest utopijna. Nie oznacza to jednak, że nie należy aktualnie obowiązujących kulturowych mechanizmów destabilizować i zmieniać w taki sposób, by nie były opresyjne, lecz miały inkluzywny charakter, a zatem nie były konstruowane w oparciu o binarny system płciowy „męskie-kobiece” i heteronormę. Uważam, że Poza schematem jest bardzo ważną lekturą, ponieważ zwraca uwagę na to, że w świecie nie ma wyłącznie mężczyzn i kobiet, choć niewątpliwie taki schemat wydaje się dla nas najbadziej bezpieczny, ponieważ prezentuje uproszczone myślenie o człowieku: o jego podmiotowości, relacyjności, a także płciowości. Pośród takiej kategoryzacji jedynym wyznacznikiem staje się płeć fenotypowa, a przecież kategoria płci jest dużo bardziej złożona, podobnie jak rzeczywistość społeczno-kulturowa, w której funkcjonujemy. Konieczne zatem jest zdekonstruowanie binarnego schematu, szczególnie w wymiarze płciowym, po to, by każdy mógł kształtować własną podmiotowość wolny od opresyjnych norm. Zaświadczają o tym z niemałą odwagą ${ }^{12}$ Kluczyńska, Dynarski i Kłonkowska.

${ }^{12}$ Dynarski pisze wprost: „Świat [...] potrzebuje nieschnącej - wiecznie gotowej (a zatem męsko aktywnej) manginy ["odbyt pasywnego partnera w cisgenderowym seksie gejowskim»]" (2016, s. 66). Jest to bardzo odważna teza, wręcz kontrowersyjna, z którą wiele osób niewątpliwie podjętoby polemikę. 


\section{Bibliografia}

Bourdieu, P. (2004). Męska dominacja. (L. Kopciewicz, tłum.). Warszawa: Oficyna Naukowa.

Butler, J. (2008). Uwikłani w płeć: Feminizm i polityka tożsamości. (K. Krasuska, tłum.). Warszawa: Wydawnictwo Krytyki Politycznej.

De Beauvoir, S. (2014). Druga płeć. (G. Mycielska, M. Leśniewska, tłum.). Warszawa: Wydawnictwo Czarna Owca.

Dynarski, W. (2016a). Kiedy binaryzm zawodzi - matczyne tranzycie, rodzący mężczyźni a homonormatywność polityki równościowej. W U. Kluczyńska, W. Dynarski, A. M. Kłonkowska (red.), Poza schematem: Społeczny konstrukt płci i seksualności (ss. 7177). Gdańsk: Wydawnictwo Uniwersytetu Gdańskiego.

Dynarski, W. (2016b). Od niedostatku do „przemokrości” - mangina, transman pride i płyny ustrojowe. W U. Kluczyńska, W. Dynarski, A. M. Kłonkowska (red.), Poza schematem: Spoleczny konstrukt ptci i seksualności (ss. 65-69). Gdańsk: Wydawnictwo Uniwersytetu Gdańskiego.

Dynarski, W. (2016c). Trzy opcje to za mało. Różnorodność transpłciowych tożsamości w badaniach społecznych. W U. Kluczyńska, W. Dynarski, A. M. Kłonkowska (red.), Poza schematem: Społeczny konstrukt płci i seksualności (21-37). Gdańsk: Wydawnictwo Uniwersytetu Gdańskiego.

Dynarski, W. (2016d). W stronę transpłciowej reprezentacji. Społeczeństwo obywatelskie a interesy osób płciowo nienormatywnych. W U. Kluczyńska, W. Dynarski, A. M. Kłonkowska (red.). Poza schematem: Społeczny konstrukt ptci i seksualności. (ss. 133145). Gdańsk: Wydawnictwo Uniwersytetu Gdańskiego.

Dynarski, W., Kłonkowska, A. M. (2016). Gender i inne kłopotliwe terminy: Czyli jak mówić o różnorodności i (nie)normatywności płciowej i seksualnej? W U. Kluczyńska, W. Dynarski, A. M. Kłonkowska (red.), Poza schematem: Społeczny konstrukt ptci $i$ seksualności (ss. 11-20). Gdańsk: Wydawnictwo Uniwersytetu Gdańskiego.

Kluczyńska, U., Dynarski W., Kłonkowska, A. M. (2016). Poza schematem: Społeczny konstrukt płci i seksualności. Gdańsk: Wydawnictwo Uniwersytetu Gdańskiego.

Kłonkowska, A. M. (2016). (Trans)mężczyźni, (trans)kobiety i seksualność. O społecznym konstruowaniu seksualności w odniesieniu do osób transpłciowych. W U. Kluczyńska, W. Dynarski, A. M. Kłonkowska (red.), Poza schematem: Społeczny konstrukt płci i seksualności (ss. 109-132). Gdańsk: Wydawnictwo Uniwersytetu Gdańskiego.

Lévinas, E. (2000). Inaczej niż być lub ponad istotą. (P. Mrówczyński, tłum.). Warszawa: Fundacja Aletheia.

Lis, B. (2015). Gejowskie (nie)męskości. Normy ptciowe a strategie tożsamościowe gejów. Gdańsk: Wydawnictwo Naukowe Katedra.

Sartre, J. P. (2007). Byt i nicość: Zarys fenomenologii ontologicznej. (J. Kiełbasa, tłum.). Kraków: Wydawnictwo Zielona Sowa. 
Sartre, J. P. (1998). Egzystencjalizm jest humanizmem. (J. Krajewski, tłum.). Warszawa: Wydawnictwo Literackie Muza SA.

Szahaj, A. (2015). Inny kapitalizm jest możliwy. Warszawa: Instytut Wydawniczy Książka i Prasa.

\title{
Źródła internetowe
}

Schemat. (2017). W Słownik Jezzyka Polskiego PWN. Źródło: http://sjp.pwn.pl/sjp/schemat;2574947.html, (20.03.2017).

Stereotyp. (2017). W Stownik Języka Polskiego PWN.

Źródło: http://sjp.pwn.pl/szukaj/stereotyp.html, (20.03.2017).

\section{Is it possible to live outside of the scheme? A book review}

\begin{abstract}
The aim of this work is to present a review of a book by Kluczyńska, Dynarski and Kłonkowska Poza schematem. Spoleczny konstrukt ptci i seksualności. The Authors describe nonbinary individuals who are entangled in the binary system of gender. Kluczyńska, Dynarski and Kłonkowska consider solutions which can help nonbinary people subjugated by the heteronorm. Through these solutions they could construct their subjectivity as free persons. The Authors argue that it is possible only outside of the (binary) scheme, which should be destabilized. In this review I would like to consider whether it is possible to live outside of the cultural scheme because - in my opinion - when we leave one scheme, we land in another one.
\end{abstract}

Keywords: scheme; heteronorm; transgenderism; cissexuality; binary sexual system 